\title{
The Relationship Of Accounting Majors' Cognitive Style And Technological Proficiency: Are Students Prepared To Enter An Increasingly Knowledge-Based Profession?
}

Lewis Shaw (E-mail: 1shaw@suffolk.edu), Suffolk University

\begin{abstract}
The increasingly knowledge-based economy has generated technological innovations that demand different competencies for accounting practitioners. In particular, professional service firms such as public accounting practices depend on converting individual expertise into codified knowledge shared within firms and with customers. A key to this knowledge conversion cycle is proficiency with a number of technological tools. Further, individuals who can successfully participate in the creation and transfer of knowledge may have distinct cognitive style characteristics. One important question is whether cognitive style is related to technological proficiency.
\end{abstract}

This study examines the cognitive styles of a group of undergraduate accounting majors (those intending careers in accounting) at several U.S. universities to examine any patterns in their cognitive style characteristics. This study further explores the relationship between cognitive style and technological proficiency. Results indicate that accounting students are predominantly linear-thinking (Concrete Sequential), consistent with prior literature. However, those who have stronger proficiency with computers and technology fit into different cognitive style groups. Implications for the accounting profession and accounting education are discussed.

\section{Introduction}

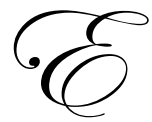

conomic society is changing from one whose creation of wealth was mainly through the manufacture of products to one in which the creation of wealth is through the capitalization of individuals within firms' collective transformation of information into knowledge. The spiral process of taking tacit knowledge in individuals, codifying it into explicit knowledge, and cycling it into strategic intellectual capital with immense value to the firm and its customers is what distinguishes the knowledge-based organization (Nonaka and Takeuchi, 1995).

As professional service firms, accounting practices are in the forefront of this knowledge management. Accountants exploit their personal knowledge and training, codify that knowledge into explicit knowledge to be shared by other members of their firms, and use that collective knowledge to provide value-added services to clients. The codification, storage, and communication of that knowledge rely heavily on innovative technologies. Although accounting has used technology for decades, the impact of knowledge management on today's organizations has elevated the role and application of technology to preeminence. Technology is essential to support the creation and dissemination of knowledge within members of global organizations as well as provide essential tools for decision support (Junnarkar and Brown, 1997). This has created a transformation in the tasks done by accountants, the way information is processed, stored, and communicated, and ultimately the skills needed by accounting professionals. 
The cognitive style of someone involved in traditional tasks of a paper-based accounting environment may be significantly different than that of someone involved as a professional in today's knowledge-based, technologyintensive environment. This research asks whether the cognitive styles of accountants who can successfully integrate advanced technological proficiency into their repertoire will differ from those attributable to the traditional accountant. This study investigates cognitive styles scores of a group of undergraduate accounting majors, those preparing to enter the profession. Further, the relationship between these students' cognitive styles and their technological proficiencies is examined.

The remainder of the paper is organized as follows. The next section discusses prior literature in the related areas of accounting transformation, technology, knowledge management, and cognitive style, and presents the research questions. The third section describes the study design and measurement instruments. The fourth section presents the results of the study. The fifth section discusses the study's conclusions, limitations, and implications for the accounting profession and accounting education.

\section{Literature Review And Research Questions}

\subsection{Knowledge Management And Accounting}

Drucker (1993), Reich (1991), and many others have described the transformation of our economy from the "industrial age" to the "information age". Wealth is generated through the exploitation of intellectual capital or intangible assets, rather than the traditionally recognized production of marketable goods and utilization of tangible assets. In a knowledge-creating company, business success is tied to codifying the tacit knowledge held by individuals and converting it into explicit knowledge shared by the entire firm (Nonaka et al., 1995). The emergence of the professional services industry as the primary driver for capital creation in our economy has transformed the structure of organizations, including public accounting practices (Empson, 1999). Technology has played a key role in the process (Zack and Serino, 1996; and others).

Knowledge management is about internal collaborative endeavors and the sharing of information and experience (Kocharekar, 2001). Effective performance and growth in a knowledge-intensive organization requires integrating and sharing highly distributed knowledge (Zack, 1999). One global accounting and consulting firm defines knowledge management as the discipline of enabling individuals in an organization to collectively acquire, share, and leverage knowledge to achieve business objectives (Duffy, 2001).

The American Institute of Certified Public Accountants (1996) among other professional bodies have identified several changes taking place in the accounting profession. One large component of this transformation is innovative technological applications (McKenney, 1995). In public accounting, traditional dominance of the auditing profit center has shifted to broader "assurance services", consulting, and other areas not previously recognized as within the accounting domain (Chambers, 1987). New performance measurement tools have been introduced, such as Stern Stewart \& Co.'s "Economic Value Added" (EVA) measure, the Balanced Scorecard" (Kaplan and Norton, 1992), and others (see Ittner and Larcker, 1999 for a review).

Sociologists (Turkle, 1995; Zuboff, 1988) have identified the impact of technology on various aspects of our professional and personal lives. Technology plays a vital role internally within organizations. It provides the vehicle by which workers and managers communicate actively. Information systems make it possible to automate office transactions and create a vast overview of an organization's operations, with many levels of data coordinated and accessible for a variety of analytical efforts (Zuboff, 1988). Information technology is a key enabler of knowledge creation (Junnarkar et al., 1997), providing knowledge management capabilities that would not have been possible otherwise (Bourdreau and Coullard, 1999). Systems integration that incorporates knowledge management thinking offers the information technology function the opportunity for organizational transformation in partnership with the rest of the organization.

Technology plays an integral part in the knowledge-based organization by creating a knowledge-based repository as a multi-user information retrieval system. All company information (both financial and non-financial) 
can be stored in a single integrated database or data warehouse, available (with restrictions) to all employees (Nonaka, 1991) ${ }^{1}$. IT infrastructure provides the base or platform upon which knowledge management solutions are built (Duffy, 2001). Intelligent computer systems facilitate the flow of knowledge through an organization (Gregor and Benbasat, 1999). Collaborative tools such as Lotus Notes ${ }^{\mathrm{TM}}$ and Lotus K-Station ${ }^{\mathrm{TM}}$ aid self-managed teams by cre-ating a natural environment within which to build a repository for rich, explicit knowledge. Content management tools try to keep the enterprise information fresh. Collaborative applications focus primarily on supporting inter-action among people holding tacit knowledge (Zack et al., 1996). Continued developments in enterprise-wide soft-ware, point-of-sale processing, networking, client/server hardware and configurations, personal workstations, com-munications through the Internet and intranets, expert systems, voice recognition, groupware, imaging, optical char-acter recognition, various wireless technologies, and other technologies have led to powerful opportunities for knowledge management (Bourdreau et al., 1999). Firms such as Ernst \& Young, KMPG, and, formerly, Arthur Andersen are often cited as leaders in the implementation of new structures designed to harness knowledge (Grant, 1997; and others).

\subsection{Cognitive Style}

Several authors have predicted that in the future the availability of information and the way in which it is accessed will rely much more heavily on thinking processes which are not linear, concrete, or sequential (Turkle, 1995; Stone et al., 1996; Landry et al., 1996). Not only will thinking processes transcend the limits of linearity and concreteness, they also will be much more abstract, random, non-sequential, and definitely non-linear in nature (Summers et al., 2000; Satava, 1997; O'Brien, 1994; Mani 1995; Landry et al., 1996). This indicates a possible shift in the cognitive styles traditionally associated with individuals in the accounting field.

Based on Nonaka and Takeuchi's (1995) model of the cycle of transfer of knowledge from tacit to explicit, individuals have different ways of processing information and viewing the world (cognition) (Grant, 1996). There is evidence that expertise and other individual characteristics, including cognitive style, have a strong impact on one's ability to function effectively within the model of the knowledge-based organization and the intelligent system (Gregor et al., 1999). The personality and cognitive traits associated with individuals involved in traditional accounting functions arguably differs from those necessary to analyze and communicate complex strategic financial and non-financial information (Stone et al., 1996; and others).

Cognitive learning styles ${ }^{2}$ can be defined as "distinctive behaviors that serve as indicators of how a person learns from and adapts to his/her environment. It also gives clues as to how a person's mind operates" (Gregorc, 1979). It has also been defined as "information processing habits representing the learner's typical mode of perceiving, thinking, problem solving, and remembering" (O'Brien, 1994). Leonard and Straus (1997) in their examination of thinking styles within the knowledge organization define cognitive differences as "varying approaches to perceiving and assimilating data, making decisions, solving problems and relating to others".

Mediation Ability Theory (a person's capacity to use channels of information) is the basis of the Gregorc Style Delineator, stating that the human mind has channels through which it receives and expresses information most efficiently and effectively (Gregorc 1982). The Styles Delineator focuses on two types of mediation abilities: perception and ordering. Perception refers to a person's ability to grasp information, and its measures are abstract and concrete. Ordering refers to the means in which one arranges, systemizes and disposes of information, and its measures are sequential and random. Gregorc states that there are other individualities that are not measured by The Style Delineator which affect human behavior, however perception and ordering are two of the more salient

1 This includes text retrieval systems, database management systems, electronic card file software, hypertext systems, executive support systems, and expert systems (Harris, 1995).

2 Dozens of diagnostic tools and descriptive analyses of human cognitive approaches to problem solving, communication, and personality have been developed. These include the Myers-Briggs Type Indicator, the Decision Style Indicator, Kolb's Learning Style Inventory, Lifescripts, Kirton's Innovator-Adaptor Inventory, Paivo's Verbal-Imagery Questionnaire, Riding's Cognitive Styles Analysis Test, and the Gregorc Styles Delineator (Bokoras et al., 1992; Riding and Cheema, 1991). Each of these instruments uses different terminology (and other design features) to describe behavioral traits that the tests are designed to measure. 
measures of style (Gregorc, 1982). Gregorc combines these characteristics - abstractness, randomness, concreteness, and sequentialness - to arrive at four mediation channels: concrete sequential (CS), concrete random (CR), abstract sequential (AS), and abstract random (AR).

Individuals classified as Concrete Sequential (CS) tend to be practical, thorough, well-organized and prefer quiet, stable, structured environments. They tend to perceive reality as the concrete world of the physical senses, and think in a sequential, orderly fashion. These individuals can detect minute details and can work with the precision of a machine. Other characteristics include practical, persistent, objective, careful with detail, thorough, perfectionistic, ordered, realistic, solid, and product-oriented. CS's are most comfortable when the system tangibly rewards hard work. They prefer highly structured meetings and work environments, and have difficulty with people who exhibit strong mood swings or frequently change their minds.

Individuals classified as Concrete Random (CR) process information in three-dimensional patterns and think intuitively, instinctively, impulsively, and independently. They prefer competitive, unrestricted, and stimulusrich environments. They tend to be risk-takers and can easily jump to conclusions, often correctly. Such individuals are divergent thinkers, thriving in areas that encourage exploration. Other descriptors include creative, troubleshooters, concerned with multi-solutions, insightful, perceptive, risk-takers, and dreamers. CS's enjoy reducing attention to facts and details and trying to discover relationships that tie them together.

Individuals classified as Abstract Sequential (AS) tend to be evaluative, analytical, and logical individuals with a preference for mentally stimulating, orderly, and quiet environments. They have academic-type minds driven by a thirst for knowledge. Such individuals perceive knowledge as powerful, and the ability to synthesize and relate concepts enables them to transmit ideas (through oral and written communication) intelligibly and eloquently. AS's can be described as logical, concerned with proof, referential, concerned with quality, judging, and rational. AS's prefer to take the time to study and discuss an issue rationally by gathering data, checking correlations, and weighing various viewpoints. They would much rather discuss serious philosophical and substantive issues rather than administrative detail and the like. They are comfortable reviewing, comparing, or synthesizing the thoughts of others and building on them. They do not relate well with adventurous people, dreamers, or people who use humor to convey ideas.

Individuals classified as Abstract Random (AR) are highly focused on the world of feeling and emotion and are sensitive, spontaneous, attuned, person-oriented people. Their thought processes tend to be nonlinear, multidimensional, emotional, perceptive, and critical. They prefer active, free, and colorful environments and thrive on building relationships with others. They tend to dislike extremely structured environments. AR's like to know that it is acceptable to change their minds or change tasks based on changes in their moods. They prefer meetings with flexible agendas. They have difficulty with practical matters and dislike individuals who get to the point rapidly, bypassing discussion and process.

The literature shows many studies of different groups of individuals that illustrate similarities in cognitive styles among these groups. Students within various areas of study as well as individuals within a given profession have been shown to demonstrate similar styles. Henry (1989) examines backgrounds and cognitive styles of medical students, demonstrating many similarities and indicators of success. Stewart and Felicetti (1992), using the Gregorc Style Delineator, examine undergraduate marketing majors and find similar scores in cognitive style. Using the Kirton Innovator-Adaptor Inventory, Richards and Gaston (1995) examine business students in a university in England, finding distinct ranges of style. Similarly, Murphy et al. (1998) examine undergraduate business majors and findings are consistent with other studies.

The study of cognitive styles has included a thorough examination of the relationship between cognitive styles and computer proficiency (Evans and Simkin, 1989). Using the Myers-Briggs Type Indicator (MBTI) (Myers and McCaulley, 1985), Jones (1994) examines university students and notes a strong relationship between cognitive style and computer use. It appears that cognitive style may play a stronger role in one's programming abilities than any prior training or experience. Important cognitive characteristics of computer programmers include the ability to 
understand abstract concepts, the ability to translate word problems into equations or other symbolic notation, the ability to outline logic in steps, and the ability to follow complex directions listed in a procedure (Evans et al., 1989).

Numerous studies of cognitive style over the past two decades have either focused on or included accounting students or practitioners (Soroko, 1988; Gul et al., 1992; Booth, 1993; Geary and Rooney, 1993; Wolk and Cates, 1994; Laribee, 1994; Auyeung and Sanders, 1996; Fisher and Ott, 1996; Gul, 1999; and others). Summers et al. (2000) compare problem-solving attributes of auditors and consultants using Kirton's AdaptorInnovator Inventory. Their study finds that those in the consulting area tend to be higher on the innovator scale, whereas those in auditing tend to be adaptors. They further posit that with the shifts in the profession demanding different characteristics of auditors, practitioners may demonstrate more job-related stress.

These studies have utilized various instruments that use different terminologies to describe attributes to cognitive style, such as verbal, imagery, adaptive, innovative, concrete, sequential, linear, abstract, random, and many others. In general, these studies characterize accountants as linear-thinking, concrete, sequential, adaptive, and various similar descriptors. With the changes taking place in the function of the accountant due to knowledge management and its related innovative technologies (AICPA, 1996; and others), the cognitive style necessary for success in the profession may be different from that of traditional accountants. In terms of cognitive style, these traits can be identified as creative, abstract, innovative, non-linear, and intuitive.

\subsection{Research Questions}

There are two research questions at the core of this study:

RQ1: What is the predominant cognitive style of a group of undergraduate accounting majors?

RQ2: Is there a relationship between cognitive style and technological proficiency in a group of undergraduate accounting majors?

\section{Study Design And Instruments}

For this study, the Gregorc Styles Delineator and a questionnaire were administered to 132 undergraduate accounting majors at four northeastern United States universities. Of the students in the study, 54 were males and 78 were females (see Table 1, Panel A). About one third were juniors and two thirds were seniors, with one graduate student (although all surveys were administered in undergraduate accounting classes) (see Table 1, Panel B). Over $57 \%$ of the students were between the ages of $21-25$, with $17 \%$ between the ages of 16 and $20^{3}$, and $7 \%$ over age 35 (see Table 1, Panel C). Grade Point Averages (GPA) ranged from 2.0 to 4.0 (on a 4.0 scale), with an average GPA of 3.235 ( $\mathrm{SD}=.426)$. The vast majority of the students reported taking between 1 and 6 computerrelated courses during their college careers, with an average of 2.2 courses taken ( $\mathrm{SD}=1.25)$ (see Table 1, Panel D).

Computer proficiency was measured by using a questionnaire, which measures self-assessed technical proficiency in the areas of computer usage and knowledge of computers, computer applications, network applications, and computer systems. This questionnaire is based on a survey of prior instruments used in various studies (Loyd and Gressard, 1984; Nickell and Pinto, 1986; Heinssen et al., 1987; Francis, 1993; Harrison and Rainer, 1997; and others). The questions were updated to incorporate the most recently available technologies deemed useful to the accounting profession.

The questionnaire utilizes a five-point Likert Scale, where 1 is the lowest possible range and 5 is the highest. Further, the section measuring students' self-assessed computer proficiencies is divided into questions at three levels. The first level is basic computer literacy skills. The second level is proficiencies well established as essential to success in accounting (for example, setting up a financial spreadsheet application). The third section focuses on advanced computer applications and skills. These include proficiency with higher-level functions of database management programs, familiarity with networked accounting applications, and the like. Various demographic data were also collected. The questionnaire was pre-tested on a sample of 50 students prior to administration of this study.

\footnotetext{
${ }^{3}$ It is assumed that within this age range are primarily students aged 19 and 20.
} 
Table 1: Respondent Demographic Attributes

\begin{tabular}{|c|c|c|}
\hline $\begin{array}{l}\text { Panel A - } \\
\text { Gender }\end{array}$ & Frequency & Percent \\
\hline Male & 54 & 40.9 \\
\hline Female & 78 & 59.1 \\
\hline Total & 132 & 100.0 \\
\hline \multicolumn{3}{|l|}{ Panel B - } \\
\hline Junior & 43 & 32.6 \\
\hline Senior & 88 & 66.7 \\
\hline Other & 1 & .8 \\
\hline Total & 132 & 100.0 \\
\hline \multicolumn{3}{|l|}{ Panel C - } \\
\hline Age & Frequency & Percent \\
\hline $16-20$ & 22 & 16.7 \\
\hline $21-25$ & 76 & 57.6 \\
\hline $26-30$ & 18 & 13.6 \\
\hline $31-35$ & 7 & 5.3 \\
\hline $36+$ & 9 & 6.8 \\
\hline Total & 132 & 100.0 \\
\hline \multicolumn{3}{|l|}{$\begin{array}{l}\text { Panel D - } \\
\text { \# Of }\end{array}$} \\
\hline Computer-Related & & \\
\hline Courses Taken & Frequency & Percent \\
\hline 0 & 4 & 3.0 \\
\hline 1 & 39 & 29.5 \\
\hline 2 & 466 & 34.8 \\
\hline 3 & 20 & 15.2 \\
\hline 4 & 17 & 12.9 \\
\hline 5 & 44 & 3.0 \\
\hline 6 & 2 & 1.5 \\
\hline Total & 132 & 100.0 \\
\hline
\end{tabular}

Cognitive style was measured using the Gregorc Style Delineator (Gregorc, 1979). It was designed as a self-analysis tool to aid an individual in recognizing and identifying channels through which he/she receives and expresses information efficiently, economically, and effectively. These channels provide a person with "mediation abilities", referred to as "style" (Gregorc, 1984).

In the Style Delineator, individuals are administered a test consisting of ten sets of four words, which they are asked to rank (' 1 ' indicating "least like me" to '4' indicating "most like me"). Each word corresponds to a particular mediation channel, and, when summed up, gives an accurate measure of an individual's propensity for operating within a specific cognitive style. With a possible score of 4 to 40 in each of the four mediation channels, Gregorc divides the scores in each area into: strong orientation as 27-40, moderate orientation as 16-26, and low orientation as below 16. Gregorc asserts that roughly $90 \%$ of individuals have a natural predisposition toward one or two of these channels and that channels serve to mediate how the individuals learn and act upon their environment (Gregorc, 1982). The remaining 10\% of individuals either have strong orientation in more than two areas or equally balanced scores in all four areas. Research studies have further shown that approximately $37 \%$ of the general population score high as Concrete Sequential, 34\% as Abstract Random, 19\% as Concrete Random, and only 10\% as Abstract Sequential (Seidel and England, 1999). Characteristics of individuals who score high in each of the four mediation channels are shown in Table 2. 
Table 2: Dominant Style Characteristics Of The Four Mediation Channels Of The Gregorc Style Delineator (1982)

\begin{tabular}{|c|c|c|c|c|}
\hline $\begin{array}{c}\text { Frames } \\
\text { Of } \\
\text { Reference } \\
\end{array}$ & $\begin{array}{l}\text { Concrete } \\
\text { Sequential } \\
\text { CS } \\
\end{array}$ & $\begin{array}{c}\text { Concrete } \\
\text { Random } \\
\text { CR } \\
\end{array}$ & $\begin{array}{c}\text { Abstract } \\
\text { Random } \\
\text { AR } \\
\end{array}$ & $\begin{array}{c}\text { Abstract } \\
\text { Sequential } \\
\text { AS } \\
\end{array}$ \\
\hline KEY WORDS & Practical & Probable & Potential & Possible \\
\hline $\begin{array}{l}\text { WORLD OF } \\
\text { REALITY }\end{array}$ & $\begin{array}{l}\text { Concrete world } \\
\text { of the physical } \\
\text { senses }\end{array}$ & $\begin{array}{l}\text { Abstract world } \\
\text { of the intellect } \\
\text { based upon } \\
\text { concrete world }\end{array}$ & $\begin{array}{l}\text { Abstract world } \\
\text { of feeling and } \\
\text { emotion }\end{array}$ & $\begin{array}{l}\text { Concrete world } \\
\text { of activity and } \\
\text { abstract world } \\
\text { of intuition }\end{array}$ \\
\hline $\begin{array}{l}\text { ORDERING } \\
\text { ABILITY }\end{array}$ & $\begin{array}{l}\text { Sequential step- } \\
\text { by-step linear } \\
\text { progression }\end{array}$ & $\begin{array}{l}\text { Sequential and } \\
\text { two-dimensional; } \\
\text { tree-like }\end{array}$ & $\begin{array}{l}\text { Random web- } \\
\text { like and multi- } \\
\text { dimensional }\end{array}$ & $\begin{array}{l}\text { Random three- } \\
\text { dimensional } \\
\text { patterns }\end{array}$ \\
\hline VIEW OF TIME & $\begin{array}{l}\text { Discrete units } \\
\text { of past, present, } \\
\text { future }\end{array}$ & $\begin{array}{l}\text { The present, } \\
\text { historical past, } \\
\text { and projected } \\
\text { future }\end{array}$ & $\begin{array}{l}\text { The moment: } \\
\text { time is artificial } \\
\text { and restrictive }\end{array}$ & $\begin{array}{l}\text { Now: total of } \\
\text { the past, } \\
\text { interactive } \\
\text { present, and } \\
\text { seed for the } \\
\text { future }\end{array}$ \\
\hline THINKING PROCESSES & $\begin{array}{l}\text { Instinctive, } \\
\text { methodical, } \\
\text { deliberate }\end{array}$ & $\begin{array}{l}\text { Intellectual, } \\
\text { logical, } \\
\text { analytical, } \\
\text { correlative }\end{array}$ & $\begin{array}{l}\text { Emotional, } \\
\text { psychic, } \\
\text { perceptive, } \\
\text { critical }\end{array}$ & $\begin{array}{l}\text { Intuitive, } \\
\text { instinctive, } \\
\text { impulsive, } \\
\text { independent }\end{array}$ \\
\hline VALIDATION PROCESS & $\begin{array}{l}\text { Personal proof } \\
\text { via the senses: } \\
\text { accredited } \\
\text { experts }\end{array}$ & $\begin{array}{l}\text { Personal } \\
\text { intellectual } \\
\text { formulae: } \\
\text { conventionally } \\
\text { accredited } \\
\text { experts }\end{array}$ & $\begin{array}{l}\text { Inner guidance } \\
\text { system }\end{array}$ & $\begin{array}{l}\text { Practical } \\
\text { demonstration: } \\
\text { personal proof: } \\
\text { rarely accepting } \\
\text { of outside } \\
\text { authority }\end{array}$ \\
\hline FOCUS OF ATTENTION & $\begin{array}{l}\text { Material reality; } \\
\text { physical objects }\end{array}$ & $\begin{array}{l}\text { Knowledge, } \\
\text { facts, } \\
\text { documentation, } \\
\text { concepts, ideas }\end{array}$ & $\begin{array}{l}\text { Emotional } \\
\text { attachments, } \\
\text { relationships, } \\
\text { and memories }\end{array}$ & $\begin{array}{l}\text { Applications, } \\
\text { methods, } \\
\text { processes, and } \\
\text { ideals }\end{array}$ \\
\hline CREATIVITY & $\begin{array}{l}\text { Product, } \\
\text { prototype, } \\
\text { refinement, } \\
\text { duplication }\end{array}$ & $\begin{array}{l}\text { Synthesis, } \\
\text { theories, models, } \\
\text { and matrices }\end{array}$ & $\begin{array}{l}\text { Imagination, the } \\
\text { arts, refinement, } \\
\text { relationships }\end{array}$ & $\begin{array}{l}\text { Intuition, } \\
\text { originality, } \\
\text { inventive, and } \\
\text { futuristic }\end{array}$ \\
\hline $\begin{array}{l}\text { ENVIRONMENTAL } \\
\text { PREFERENCE }\end{array}$ & $\begin{array}{l}\text { Ordered, } \\
\text { practical, quiet, } \\
\text { stable }\end{array}$ & $\begin{array}{l}\text { Mentally } \\
\text { stimulating, } \\
\text { ordered and } \\
\text { quiet, non- } \\
\text { authoritative }\end{array}$ & $\begin{array}{l}\text { Emotional and } \\
\text { physical } \\
\text { freedom; rich; } \\
\text { active and } \\
\text { colorful }\end{array}$ & $\begin{array}{l}\text { Stimulus-rich, } \\
\text { competitive, } \\
\text { free from } \\
\text { restriction }\end{array}$ \\
\hline USE OF LANGUAGE & $\begin{array}{l}\text { Literal meaning } \\
\text { and labels, } \\
\text { succinct, logical }\end{array}$ & $\begin{array}{l}\text { Polysyllabic } \\
\text { words, precise, } \\
\text { rationality; } \\
\text { highly verbal }\end{array}$ & $\begin{array}{l}\text { Metaphoric, } \\
\text { uses gestures } \\
\text { and body } \\
\text { language; } \\
\text { colorful }\end{array}$ & $\begin{array}{l}\text { Informative, } \\
\text { lively, colorful; } \\
\text { "words do not } \\
\text { convey true } \\
\text { meaning" }\end{array}$ \\
\hline $\begin{array}{l}\text { PRIMARY EVALUATIVE } \\
\text { WORD(S) }\end{array}$ & Good, Not Bad & Excellent & $\begin{array}{l}\text { Super, Fantastic, } \\
\text { Marvelous }\end{array}$ & Great, Superior \\
\hline $\begin{array}{l}\text { NEGATIVE } \\
\text { CHARACTERISTICS }\end{array}$ & $\begin{array}{l}\text { Excessive } \\
\text { conformity; } \\
\text { unfeeling, } \\
\text { possessive }\end{array}$ & $\begin{array}{l}\text { Opinionated, } \\
\text { sarcastic, aloof }\end{array}$ & $\begin{array}{l}\text { Spacey, overly } \\
\text { sensual, } \\
\text { smothering }\end{array}$ & $\begin{array}{l}\text { Deceitful, } \\
\text { unscrupulous, } \\
\text { ego-centric }\end{array}$ \\
\hline
\end{tabular}




\section{Results}

In the area of technological proficiency, questions were divided into three levels - basic (level 1), intermediate (level 2), and advanced (level 3). Out of a possible 25 points for each level, the level 1 proficiency was self-reported as an average of $18.08 \quad(\mathrm{SD}=3.66)$. Level 2 proficiency was 16.03 ( $\mathrm{SD}=4.53)$, and level 3 proficiency (database management, network applications, etc.) was an average of 11.61 points $(\mathrm{SD}=5.09)$. Overall self-reported computer proficiency averaged 45.71 (out of a possible 75 points) ( $\mathrm{SD}=11.82$ ) (see Table 3 ).

Table 3: Computer Proficiency Scores

\begin{tabular}{|l|c|c|c|c|c|}
\hline $\begin{array}{l}\text { Computer } \\
\text { Proficiency }\end{array}$ & N & Minimum & Maximum & Mean & $\begin{array}{c}\text { Std. } \\
\text { Deviation }\end{array}$ \\
\hline $\begin{array}{l}\text { Level 1 } \\
\text { Computer } \\
\text { Proficiency }\end{array}$ & 132 & 9 & 25 & 18.08 & 3.66 \\
\hline $\begin{array}{l}\text { Level 2 } \\
\text { Computer } \\
\text { Proficiency }\end{array}$ & 132 & 5 & 25 & 16.03 & 4.53 \\
\hline $\begin{array}{l}\text { Level 3 } \\
\text { Computer } \\
\text { Proficiency }\end{array}$ & 132 & 5 & 25 & 11.61 & 5.09 \\
\hline $\begin{array}{l}\text { Overall } \\
\text { Computer } \\
\text { Proficiency }\end{array}$ & 132 & 19 & 75 & 45.71 & 11.82 \\
\hline
\end{tabular}

Table 4: Distribution Of Mediation Channels

\begin{tabular}{|l|r|r|c|}
\hline Mediation Channel & N & Percent & $\begin{array}{c}\text { Group } \\
\text { Percent }\end{array}$ \\
\hline CS & 32 & 24.24 & 24.24 \\
\hline CS \& AS & 40 & 7.58 & \\
\hline CS \& AR & 10 & 4.55 & \\
\hline CS \& AS \& AR & 3 & 3.79 & \\
\hline CS \& CR & 4 & 30.30 & 46.21 \\
\hline AS & 10 & 7.58 & \\
\hline AR & 6 & 2.27 & \\
\hline CR & 5 & 3.03 & \\
\hline AS \& AR & 3 & 3.03 & \\
\hline AS \& CR & 9 & 2.27 & \\
\hline AR \& CR & 6 & 6.82 & \\
\hline None & 4 & 4.55 & 29.55 \\
\hline Total & 132 & 100.00 & 100.00 \\
\hline
\end{tabular}

For this analysis, cognitive style scores were coded as $0=$ not Concrete Sequential, $1=$ Concrete Sequential only, 2= Concrete Sequential and at least one other cognitive style ${ }^{4}$. An examination of students' scores on the Gregorc Styles Delineator is shown in Table 4. Almost one quarter of the students in the sample scored high as Concrete Sequential only (characteristics of each style are summarized in Table 2). Over $46 \%$ scored high in

\footnotetext{
${ }^{4}$ Few students scored high in any of the other three cognitive style channels, necessitating this codification.
} 
Concrete Sequential and in one or more other channels ${ }^{5}$. Thus, approximately $70 \%$ of the accounting majors sampled were either purely Concrete Sequential or "mixed" Concrete Sequential ${ }^{6}$.

Results indicate that there is a moderately significant (sig.=.059) relationship between Concrete Sequentialness and computer proficiency, where non-Concrete Sequentials scored higher than either pure Concrete Sequentials or mixed Concrete Sequentials (Table 5). Further $t$-tests were conducted on pairs of cognitive style scores (0's vs. 1's, 0's vs. 2's, 1's vs. 2's) which indicate that non-Concrete Sequentials scored higher on the computer proficiency test than both Concrete Sequentials and mixed Concrete Sequentials. Non-Concrete Sequentials received a mean score of 49.21 ( $\mathrm{SD}=11.73$ ) (out of a possible 75 points), compared to Pure Concrete Sequential mean score of 43.21 ( $\mathrm{SD}=11.69$ ) and Mixed Concrete Sequential mean score of 44.21 (SD=11.57). This indicated a between-groups significance of 0.059. Between-group significance between Pure Concrete Sequentials and Non-Concrete Sequentials was even lower (0.047). The significance between Non-Concrete Sequentials and Mixed Concrete Sequentials was 0.037, showing that Concrete Sequentials did, in fact, score measurably lower on computer proficiency than Non-Concrete Seqentials.

Table 5: Computer Proficiency And Cognitive Style

\begin{tabular}{|c|c|c|c|c|c|c|c|c|}
\hline $\begin{array}{c}\text { Mediation } \\
\text { Channel }\end{array}$ & $\mathbf{N}$ & $\begin{array}{c}\text { Mean Score } \\
\text { on } \\
\text { Computer } \\
\text { Proficiency }\end{array}$ & $\begin{array}{c}\text { Std. } \\
\text { Deviation }\end{array}$ & Std. Error & \begin{tabular}{|c|}
$95 \%$ \\
Confidence \\
Interval for \\
$\begin{array}{c}\text { Mean Lower } \\
\text { Bound }\end{array}$ \\
\end{tabular} & $\begin{array}{l}\text { Upper } \\
\text { Bound }\end{array}$ & Minimum & Maximum \\
\hline 0 & 43 & 49.21 & 11.73 & 1.79 & 45.60 & 52.82 & 24 & 71 \\
\hline 1 & 32 & 43.69 & 11.69 & 2.07 & 39.47 & 47.90 & 23 & 75 \\
\hline 2 & 57 & 44.21 & 11.57 & 1.53 & 41.14 & 47.28 & 19 & 67 \\
\hline Total & 132 & 45.71 & 11.82 & 1.03 & 43.68 & 47.75 & 19 & 75 \\
\hline
\end{tabular}

$0=$ non-Concrete Sequential

$1=$ Concrete Sequential only

$2=$ Concrete Seq

\section{Conclusion}

This study examines cognitive style and the relationship between cognitive style and technological proficiency in a group of accounting students at the undergraduate level in the United States. Students were given a cognitive styles assessment test and asked to complete a self-designed technology questionnaire, assessing three levels of computer proficiency. Further, substantial demographic information was also obtained, including age, gender, grade point average (GPA), and number of computer-related courses taken.

Results yielded many insights into the make-up of today's undergraduate accounting majors. First, a large number of the subjects fit into a specific cognitive style. The attributes of this style match those that would be typical of a traditional accountant, whose strengths are in processing information sequentially in an orderly and precise manner. This type of individual prefers work under specific instructions, is product-oriented, needs highly structured environments in which to function, dislikes chaos or change, and cannot deal well with individuals who think differently than he/she does. These characteristics do not fit well with today's knowledge worker in a multidisciplinary, team-based environment such as a large accounting practice.

The results of this study further show that the subjects who fit within the cognitive style described above had measurably lower scores in computer proficiency than the students who had different cognitive styles. Since

\footnotetext{
5 Gregorc's assessment of 27+ was used as the criterion for each score.

6 As previously mentioned, approximately $37 \%$ of the general population are classified as Concrete Sequential.
} 
technology is essential in order for the knowledge organization to succeed, individuals in knowledge organizations, including accounting firms, need to have a very strong ability to utilize technology to develop intangible assets that add value to firms and their customers. The effect of cognitive styles on the accounting profession offers insights into retention and professional services.

There are several limitations of this study that are worth noting. The Gregorc Style Delineator, although a well-validated cognitive style measurement instrument, was used, whereas most studies of this nature employ the Myers-Briggs Type Indicator. The MBTI classifies factors related to cognitive style and various personality-related attributes. Although more time consuming to administer, the MBTI provides a broader range of style categories for analysis. The Gregorc Style Delineator was used in this study for two important reasons. It isolates purely cognitive dimensions using mediation theory, whereas most of the other available instruments also examine personality, emotional aspects, and other factors. Second, it can be administered in less than five minutes, which allows for access to more subjects for this and later studies. Another limitation is the sample and sample size. Subjects were obtained from four universities in the northeast United States. None of the four would be considered "top tier" schools. Perhaps a broader and larger sample would have resulted in a broader range of cognitive style characteristics of accounting majors. Further, there are other avenues to entry into professional accounting than an undergraduate accounting concentration. Lastly, technological proficiency was based on self assessment rather than an actual examination of proficiencies.

As a follow-up to this study, we are examining accounting practitioners at various levels and in all areas of professional practice in the US and the UK for cognitive style and technological proficiency. If, as suggested here, the majority of accounting majors fall within the Concrete Sequential range, therefore those entering practice would fit that group. If this type of individual is in fact ill-suited for today's knowledge-based accounting practice, either early attrition might weed out many, leaving those with other styles in the higher ranks of practice, or socialization might allow Concrete Sequential accountants to adapt to the new demands on practitioners in a knowledge-based environment.

This study identifies some of the challenges facing the accounting profession and accounting education of late. In various studies, the AICPA and other professional bodies have identified the changing role of the accountant within the organization (IMA, 1994; AICPA, 1996; IMA, 1999; AICPA, 2000; and others). These studies call for increased competencies in technology, as well as in communication and analytical skills. The Accounting Education Change Commission (AECC, 1990) has called for additional competencies in accounting graduates. Albrecht and Sack's (2000) recent report illustrates several deficiencies in current accounting curricula and dissatisfaction felt by accounting practitioners. Initiatives to redesign accounting curricula, update professional certification examinations, and attract and train appropriately suited individuals for the accounting profession are needed.

\section{References}

1. AECC. 1990. "Objectives for Accountants: Position Statement No.1". Issues in Accounting Education: 307-312.

2. $\quad$ AICPA. 1996. Information Technology Competencies in the Accounting Profession.

3. AICPA. 2000. AICPA Core Competency Framework for Entry into the Accounting Profession: AICPA.

4. Albrecht, W. S., \& Sack, R. J. 2000. Accounting Education: Charting the Course through a Perilous Future: American Accounting Association.

5. Auyeung, P., \& Sanders, J. 1996. "A cross cultural study of the learning style of accounting students". Accounting and Finance, Vol. 36: 261-274.

6. Bokoras, M. A., Goldstein, M. B., \& Sweeney, M. M. 1992. "Common factors in five measures of cognitive style". Current Psychology: Research \& Reviews, Vol. 11(No. 2): 99-109.

7. Booth, P. 1993. "Personality biases of accounting students: Some implications for learning style preferences". Accounting and Finance, 33(2): 109(112).

8. Bourdreau, A., \& Coullard, G. 1999. "Systems integration and knowledge management". Information Systems Management, 16(4): 24-34.

9. $\quad$ Chambers, A. 1987. Computer Auditing. 
10. Drucker, P. F. 1993. "Toward a knowlede-based society". The Post-Capitalist World, current ( No. 350): 4-10.

11. Duffy, J. 2001. "The tools and technologies needed for knowledge management". Information Management Journal, 25(1): 64-68.

12. Empson, L. 1999. "Knowledge management: in search of the philosophers' stone". Business Strategy Review, Vol. 10( No. 2): 67-71.

13. Evans, G. E., \& Simkin, M. G. 1989. "What best predicts computer proficiency?" Communications in the ACM, Vol. 32(No. 11): 1322-1328.

14. Fisher, D. G., \& Ott, R. L. 1996. "A study of the relationship between accounting students' moral reasoning and cognitive styles". Research on Accounting Ethics, Vol. 2: 51-71.

15. Francis, L. J. 1993. "Measuring attitude toward computers among undergraduate college students: the affective domain", Computers in Education., Vol. 20(No. 3): 251-255.

16. Geary, W. T., \& Rooney, C. J. 1993. "Designing accounting education to achieve balanced intellectual development". Issues in Accounting Education: 60-70.

17. Grant, R. M. 1996. "Toward a knowledge-based theory of the firm". Strategic Management Journal, Vol. 17: 109-122.

18. Grant, R. M. 1997. "The knowledge-based view of the firm: implications for management practice". Long Range Planning, Vol. 30( No. 3): 450-454.

19. Gregor, S., \& Benbasat, I. 1999. "Explanations from intelligent systems: theoretical foundations and implications for practice". MIS quarterly, 23(4): 497-531.

20. Gregorc, A. F. 1979. "Learning/teaching styles: potent forces behind them". Educational Leadership: 234237.

21. Gregorc, A. F. 1982. An Adult's Guide to Style. Educational Leadership.

22. Gregorc, A. F. 1984. Gregorc Style Delineator: Development, Technical and Administrative Manual. Columbia.

23. Gul, F., Huang, \& Subramaniam, N. 1992. "Cognitive style as a factor in accounting students' perceptions of career-choice factors". Psychological Reports, Vol. 71: 1275-1281.

24. Gul, F. A. 1999. "Qualified audit reports, field dependence cognitive style, and their effects on decision making". Accounting and Finance, Vol. 30(No. 2): 15-27.

25. Harris, D. B. 1995. "Creating a knowledge centric information technology environment". Unpublished paper.

26. Harrison, A. W., \& Rainer Jr., R. K. 1997. "Testing the self-efficacy - performance linkage of social cognitive theory". Journal of Social Psychology, 137(1): 79-88.

27. Heinssen Jr., Robert, K., Glass, C. R., \& Knight, L. A. 1987. “Assessing computer anxiety: development and validation of the computer anxiety rating scale". Computers in Human Behavior, Vol. 3: 49-59.

28. Henry, P. 1989. "Relationship between academic achievement and measuring career interest: examination of Holland's theory". Psychological Reports, Vol. 64: 35-40.

29. IMA. 1994. What corporateAmerica wants in entry-level accountants. Montvale, NJ: IMA.

30. IMA. 1999. Counting more, counting less: Transformations in the management accounting profession. Montvale, NJ: Institute of Management Accountants.

31. Ittner, C. D., \& Larcker, D. F. 1999. "Innovations in performance measurement: trends and research implications". Journal of Management Accounting Research, Vol. 10(No. 4): 363-382.

32. Jones, W. P. 1994. "Computer use and cognitive style". Journal of Research on Computing in Education, Vol. 26 ( No. 4): 514-523.

33. Junnarkar, B., \& Brown, C. V. 1997. "Re-assessing the enabling role of information technology in KM". Journal of Knowledge Management, 1(2): 142-148.

34. Kaplan, R. S., \& Norton, D. P. 1992. "The balanced scorecard measures that drive performance". Harvard Business Review, Vol. 70(No. 1): 71-80.

35. Kocharekar, R. 2001. "K-Commerce: Knowledge-based commerce architecture with convergence of ecommerce and knowledge management”. Information Systems Management, 18(2): 30-37.

36. Landry, J., Raymond, M., Rogers, R. L., \& Harrell, H. W. 1996. "Computer Usage and Psychological Type Characteristics in Accounting Students". Journal of Accounting and Computers, Vol. 12. 
37. Laribee, S. F. 1994. "The psychological types of college accounting students". Journal of Psychological Type, 28: 37-42.

38. Leonard, D., \& Straus, S. 1997. "Putting your company's whole brain to work". Harvard Business Review.

39. Loyd, B. H., \& Gressard, C. 1984. "Reliability and factorial validity of computer attitude scales". Educational and Psychological measurement, Vol. 44: 501-505.

40. Mani, B. 1995. "Progress on the journey to total quality management: using the Myers-Briggs Type Indicator and the adjective check list in management development". Public Personal Management, Vol. 24(No. 3): 365-406.

41. McKenney, J. L. 1995. Waves of Change: Evolution through Information Technology.

42. Murphy, H. J., Kelleher, W. E., Doucette, P. A., \& Yo, J. D. 1998. "Test-retest reliability and construct validity of the cognitive style index for business undergraduates". Psychological Reports, Vol. 82: 595-600.

43. Myers, I. B., \& McCaulley, M. H. 1985. Manual: A Guide to the Development and Use of the MyersBriggs Type Indicator. Consulting Psychologists Press.

44. Nickell, G. S., \& Pinto, J. N. 1986. "The computer attitude scale”. Computers in Human Behavior, Vol. 2: 301-306.

45. Nonaka, I. 1991. "The knowledge-creating company". Harvard Business Review.

46. Nonaka, I., \& Takeuchi, H. 1995. The Knowledge-Creating Company. New York: Oxford University Press.

47. O'Brien, T. P. 1994. "Cognitive learning styles and academic achievement in secondary education". Journal of Research and Development in Education, Vol. 28(No. 1): 11-12Walker, Kenton B., Eric L. Denna.

48. Reich, R. B. 1991. The Work of Nations. New York: Alfred A. Knopf.

49. Richards, T., \& Gaston, K. 1995. "A re-examination of personal and group estimates of the Kirton Adaption-Innovation scores”. Psychological Reports, Vol. 77: 491-498.

50. Riding, R., \& Cheema, I. 1991. "Cognitive Styles - an overview and integration”. Educational Psychology, Vol. 11(Nos. 3 and 4).

51. Satava, D. 1997. "Extraverts or introvers: who supervises the most CPA staff member?" Journal of Psychological Type, Vol. 43: 40-43.

52. Seidel, L. E., \& England, E. M. 1999. “Gregorc's cognitive styles: college students' preferences for teaching methods and testing techniques". Perceptual and Motor Skills, Vol. 88: 859-875.

53. Soroko, M. P. 1988. "Student learning styles - a teaching consideration in the principles of accounting courses". Journal of Education for Business.

54. Stewart, K. L., \& Felicetti, L. A. 1992. "Learning styles of marketing majors". Educational Research Quarterly, Vol. 15(No. 2): 15-23.

55. Stone, D. V., Arunachalam, V., \& Chandler, J. S. 1996. “An Empirical Investigation of Knowledge, Skill, Self-Efficacy and Computer Anxiety in Accounting Education". Issues in Accounting Education, Vol. 11(No. 2).

56. Summers, S. L., Sweeney, J. T., \& Wolk, C. M. 2000. "Problem-solving style and fit in consulting and auditing". Journal of Information Systems, 14(1): 1-15.

57. Turkle, S. 1995. Life on the Screen: Identity in the Age of the Internet. New York: Touchstone.

58. Wolk, C., \& Cates, T. A. 1994. "Problem-solving styles of accounting students: are expectations of innovation reasonable". Journal of Accounting Education, Vol. 12(No. 4): 269-281.

59. Zack, M. H. 1999. "Managing codified knowledge”. Sloan Management Review, 40(4): 45-58.

60. Zack, M. H., \& Serino, M. 1996. "Knowledge management and collaboration technologies", White Paper. Lotus Institute.

61. Zuboff, S. 1988. In the Age of the Smart Machine: The Future of Work and Power. Basic Books. 